\title{
Hubungan Pendidikan dan Pelatihan Terhadap Efektivitas Kerja Tenaga Kependidikan di SMA Negeri 12 Makassar
}

\author{
Mislia \\ Universitas Pejuang Republik Indonesia \\ misliagauk@yahoo.com
}

\begin{abstract}
ABSTRAK
Penelitian ini adalah penelitian kuantitatif yang bertujuan untuk mengetahuai Apakah Terdapat Hubungan yang signifikan Pendidikan dan Pelatihan Terhadap Efektivitas Kerja Tenaga Kependidikan di SMA Negeri 12 Makassar. Tempat dan waktu dalam penelitian ini adalah SMA Negeri 12 Makassar, pada bulan September 2019 tahun Pelajaran 2019/2020. Populasi adalah Tenaga Kependidikan di SMA Negeri 12 Makassar yang telah mengikuti pendidikan dan pelatihan sebanyak 48 orang yang terdiri dari 15 laki-laki dan 33 perempuan. Sampel yang digunakan adalah sampel jenuh. Teknik pengumpulan data yang digunakan adalah angket dan dokumentasi dengan teknik analisis data menggunakan uji product moment. Hasil penelitan menunjukkan bahwa Pelaksanaan pendidikan dan pelatihan mempunyai hubungan signifikan terhadap efektivitas kerja tenaga kependidikan di SMA Negeri 12 Makassar. Hasil perhitungan uji p-value pada taraf signifikansi $\alpha=$ 0.05 dan $\mathrm{n}=12$ dengan pengujian 2 pihak $\mathrm{dk}=\mathrm{n}-2=48-2=46$, diperoleh $0,02<0,05$. Faktor yang mempengaruhi efektifitas kerja adalah (a) Waktu, (b) Tugas, (c) Produktivitas, (d) Motivasi, (e) Evaluasi Kerja, (f) Perlengkapan dan Fasilitas, (g) Lingkungan Kerja, dan (h) Kemampuan Intelektual, dan (i) Pengawasan.
\end{abstract}

Kata kunci: Pendidikan, Pelatihan, Efektivitas kerja

\begin{abstract}
This research is a quantitative study that aimed to find out whether there is a significant relationship between education and training and the effectiveness of educational staff in SMA Negeri 12 Makassar. This study was counducted at SMA Negeri 12 Makassar, on September Academic year 2019/2020. The population is the educational staff at SMA Negeri 12 Makassar who have participated in education and training as many as 48 people consisting of 15 men and 33 women. The sample used is a saturated sample. Data collection techniques used were questionnaires and documentation with data analysis techniques by using product moment test. The results of the research shows that the implementation of education and training has a significant relationship to the effectiveness of the work of the educational staff at SMA Negeri 12 Makassar. The results of the calculation of the p-value test at the significance level $\alpha=0.05$ and $n=12$ by testing 2 sided, $d f=n-2=48-2=46$, obtained 0.02 $<0.05$. Factors affecting work effectiveness are (a) Time, (b) Tasks, (c) Productivity, (d) Motivation, (e) Work Evaluation, ( $f$ ) Equipment and Facilities, ( $g$ ) Work Environment, and (h) Intellectual Capability, and (i) Supervision.
\end{abstract}

Keywords: Education; Training; Work effectiveness

\section{PENDAHULUAN}

Sistem kepegawaian yang dianut di Indonesia merupakan perpaduan antara sistem karier dan sistem prestasi kerja. Dalam menciptakan pegawai yang terampil, berdaya guna dan berhasil guna, maka cara yang dilakukan adalah pemberian kesempatan kepada para pegawai untuk meningkatkan kemampuannya dalam bentuk pendidikan dan pelatihan. Siagian (2001) mengatakan bahwa: "Pentingnya pendidikan dan pelatihan sebagai suatu investasi dalam bidang sumber daya manusia yang tidak bisa tidak, harus dilaksanakan oleh setiap organisasi, apabila organisasi yang bersangkutan ingin, bukan saja untuk meningkatkan efiseinsi dan efektivitas kerjanya, akan tetapi juga dalam rangka mempercepat penetapan perwujudan perilaku organisasi yang diinginkan". Berdasarkan pendapat tersebut diatas maka, tanpa adanya pendidikan dan pelatihan dalam pembinaan pembangunan karir personal, sudah tentu 
proses pencapaian tujuan serta organisasi pada umumnya dan khususnya bagi lembaga pendidikan akan mengalami hambatan, baik dalam jangka pendek maupun jangka panjang.

Ahli manajemen lain mengatakan; "Supaya pegawai dapat melaksanaan pekerjaan lebih efisien. Supaya pengawas lebih sedikit terhadap terhadap pegawai administrasi, supaya pegawai lebih cepat berkembang dan menstabilkan pegawai, maka perlu adanya pengembangan kemampuan dan keterampilan". (Anonim, 2000)

Rosidah mengatakan:"Bahwa salah satu cara yang dapat dilakukan dalam upaya dalam meningkatkan efektivitas kerja pegawai adalah dengan melalui pengembangan yaitu dengan melakukan pendidikan dan pelatihan. Pengembangan pegawai juga sangat diperlukan dalam sebuah instansi, karena dengan adanya program tersebut dapat membantu pegawai agar lebih efektif dan efesien dalam menjalankan suatu pekerjaan dengan kata lain dapat mempercepat suatu proses pekerjaan yang berdampak meningkatkan mutu organisasi." (Sulistiyani \& Rosidah, 2003)

Pengembangan pegawai juga dirancang untuk memperoleh pegawai pegawai yang mampu berprestasi dan fleksibel untuk suatu instansi dalam geraknya kemasa depan. (Soekidjo, 2009)

Dari pengertian diatas, maka pengembangan pegawai merupakan faktor yang penting dalam rangka meningkatkan pembinaan tenaga kependidikan sekolah yang berdasarkan kemampuan dan keterampilan, penuh rasa pengabdian dan mempunyai tangung jawab yang tinggi terhadap pengembangan lembaga pendidikan.

Terlebih lagi dalam menghadapi tugas yang semakin kompleks di dalam perkembangan teknologi modern, menuntut keterampilan yang harus dimiliki oleh tenaga kependidikan sekolah. Untuk mencapai hasil yang berdaya guna dan berhasil guna dengan sebesar-besarnya, maka perlu dilaksanakan suatu pendidikan dan pelatihan. Melihat fakta bahwa pelaksanaan pendidikan dan pelatihan untuk tenaga kependidikan itu sangat berperan dalam pengelolaan administrasi sekolah, maka tenaga kependidikan yang berada di dalam satuan pendidikan tertentu didefenisikan dengan merujuk kepada Undang-undang Nomor 20 tahun 2003 Tentang Sistem Pendidikan Nasional yaitu "anggota masyarakat yang mengabdikan diri dan diangkat untuk menunjang penyelenggaraan pendidikan" (Undang-undang Nomor 20 Tahun 2003 Tentang SistemPendidikan Nasional. Pasal 1 Ayat 1 Bab 1) seorang tenaga kependidikan dalam satuan pendidikan diangkat dan didaya gunakan untuk menjalani tugas-tugas yang sesuai dengan bidang dan keahlianya masing-masing dan mendukung semua program-program yang disusun oleh kepala sekolah demi tercapainya sebuah tujuan sekolah dengan efektif dan efisien.

Berdasarkan data dan keadaan yang ada di tenaga kependidikan di SMA Negeri 12 Makassar, hasil kerja yang dicapai sebelum pelaksanaan pendidikan dan pelatihan kurang memuaskan, baik dari segi administrasi seperti penyusunan maupun dari segi pelayanan administrasi siswa dan guru. Hal lain yang ditemukan juga, bahwa hampir semua tenaga kependidikan telah mengikuti pendidikan dan pelatihan, namun belum dapat diidentifikasi sejauhmana pengaruh atau hubungan Pendidikan dan pelatihan dapat menunjang efektivitas kerja tenaga kependidikan di SMAN 12 Makassar. Oleh karena itu, untuk mencari fakta tersebut, maka rumusan masalah yang ditetapkan adalah "Apakah Terdapat Hubungan yang signifikan Pendidikan dan Pelatihan Terhadap Efektivitas Kerja Tenaga Kependidikan di SMA Negeri 12 Makassar".

Efektivitas kerja adalah sebuah kriteria pengukuran keberhasilan dari suatu pekerjaan. Untuk itu agar dapat melaksanakan pekerjaan atau kegiatan yang ditangani sehingga dapat dirasakan lebih efektif dan efesien, maka perlu adanya peningkatan pengetahuan tenaga kependidikan yaitu dengan pendidikan dan pelatihan. Terdapat beberapa faktor Yang mempengaruhi efektifitas kerja, antara lain adalah (a) Waktu, (b) Tugas, (c) Produktivitas, (d) Motivasi, (e) Evaluasi Kerja, (f) Perlengkapan dan Fasilitas, (g) Lingkungan Kerja, dan (h) Pengawasan

Menurut Stan (1993) mengatakan bahwa faktor-faktor yang mempengaruhi efektivitas kerja pegawai adalah organisasi itu sendiri, kegiatan-kegiatan itu sendiri, sifat pekerjaan, teman teman sejawat mereka. Untuk mengetahui apakah ada hubungan pendidikan dan pelatihan terhadap efektivitas kerja, maka diangkat hipotesis dalam uraian ini adalah sebagai berikut:

Ho: Tidak terdapat hubungan yang signifikan antara pendidikan dan pelatihan terhadap efektivitas kerja tenaga kependidikan di SMA Negeri 12 Makassar

Ha: Terdapat hubungan yang signifikan antara pendidikan dan pelatihan 
terhadap efektivitas kerja tenaga kependidikan di SMA Negeri 12 MakassarPendahuluan mencakup tinjauan pustaka, latar belakang, status ilmiah dewasa ini, permasalahan atau rumusan masalah, serta tujuan dan manfaat dari penelitian. Tinjauan pustaka diperlukan untuk mengetahui perkembangan subjek yang sama yang dilakukan oleh penulis dalam khazanah ilmu pengetahuan yang sudah ada.

\section{METODE PENELITIAN}

Metode yang digunakan dalam penelitian ini adalah metode kuantitatif. Penelitian ini dilakukan di SMA Negeri 12 Makassar. Variabel yang diukur adalah pendidikan dan pelatihan serta efektivitas kerja. Teknik pengumpulan data yang digunakan adalah angket dan dokumentasi. Teknik analisis data meliputi Korelasi Product Moment, skala interpretasi, koefisien diterminan dan uji signifikansi.

\section{HASIL \& PEMBAHASAN}

\section{Hasil Penelitian}

\section{a. Pendidikan dan Pelatihan}

Pendidikan dan pelatihan adalah variabel independent dalam penelitian ini. Variabel ini dijelaskan melalui angket dengan menggunakan analisis statistik deskriptif. Hasil analisis variabel ini di jelasakan pada tabel berikut:

Tabel 2: Pendidikan dan Pelatihan Yang Diberikan Kepada Tenaga Kependidikan Berguna Untuk Meningkatkan Tupoksinya

\begin{tabular}{|c|c|c|c|c|}
\hline$\overline{\text { No }}$ & & Jawaban Alternatif & $\mathbf{F}$ & $\%$ \\
\hline \multirow[t]{6}{*}{1} & a. & Sangat Setuju & 27 & 56,25 \\
\hline & b. & Setuju & 21 & 43,75 \\
\hline & c. & Kurang Setuju & 0 & 0 \\
\hline & d. & Tidak Setuju & 0 & 0 \\
\hline & e. & Sangat Tidak Setuju & 0 & 0 \\
\hline & & Jumlah & 48 & 100 \\
\hline
\end{tabular}

Pada tabel 2 terlihat bahwa tenaga kependidikan sangat setuju dengan pendidikan dan pelatihan berguna untuk meningkatkan tupoksi yang berjumlah 27 orang atau 56,25 $\%$, kemudian yang menyatakan setuju berjumlah 21 orang atau $43,75 \%$, sedangkan kurang setuju, tidak setuju, dan sangat tidak setuju tidak ada yang memilih.

\section{Analisis Hasil Skor Angket}

Untuk mengetahui Pengaruh Pendidikan dan Pelatihan Terhadap Efektivitas Kerja Tenaga Kependidikan di SMA Negeri 12 Makassar, maka diperlukan suatu teknik analisis data inferensial. Dalam hal ini yang akan dianalisis data adalah data tentang hubungan pendidikan dan pelatihan sebagai independent variabel (X) dan tentang efektivitas kerja sebagai dependent variabel (Y).

Langkah-langkah yang dilakukan adalah sebagai berikut:

1. Mengasumsikan bahwa persyaratan untuk menggunakan analisa product moment telah terpenuhi.

2. Ha dan Ho dalam bentuk kalimat.

a. Ha : Terdapat hubungan yang signifikan antara pendidikan dan pelatihan terhadap efektivitas kerja tenaga kependidikan di SMA Negeri 12 Makassar.

b. Ho : Tidak terdapat hubungan yang signifikan antara pendidikan dan pelatihan terhadap efektivitas kerja tenaga kependidikan di SMA Negeri 12 Makassar.

3. Ha dan Ho dalam bentuk Statistik
a. $\mathrm{Ha} \quad: \mathrm{r} \# 0$
b. Ho $: r=0$

Berdasarkan hasil analisis uji product moment dengan mengambil $\alpha=0.05$ dan $n=$ 48 maka dilakukan pengujian 2 pihak $\mathrm{dk}=\mathrm{n}-2$ $=48-2=46$, sehingga diperoleh $\mathrm{p}$-value $=0.02$ $<\alpha=0.05$, sehingga dapat diambil kesimpulan maka Ho ditolak atau $\mathrm{Ha}$ diterima, yang artinya, terdapat hubungan yang signifikan antara pendidikan dan pelatihan terhadap efektivitas kerja tenaga kependidikan di SMA Negeri 12 Makassar.

\section{Pembahasan}

Sejalan dengan perkembangan dan tuntutan zaman maka tantangan yang dihadapi seseorang semakin bertambah banyak. Disinilah letak pentingnya Pendidikan dan pelatihan seseorang dalam menghadapi masalah untuk menemukan pemecahannya.

Fungsi pendidikan dan pelatihan adalah :

a. Memperbaiki kinerja (performance) para peserta.

b. Mempersiapkan promosi ketenagakerjaan pada jabatan yang lebih rumit dan sulit.

c. Mempersiapkan tenaga kerja pada jabatan yang lebih tinggi yaitu tingkatan kepengawasan atau manajerial.

d. Dapat membantu karyawan membuat keputusan yang lebih baik.

e. Meningkatkan kemampuan di bidang kerjanya sehingga dapat mengurangi stres dan menambah rasa percaya diri. 
f. Sebagai proses penumbuhan intelektualitas sehingga kecemasan menghadapi perubahan di masa-masa mendatang dapat dikurangi.

Hasil penelitian di SMAN 12 Makassar menunjukkan bahwa terdapat hubungan yang signifikan antara pendidikan dan pelatihan terhadap efektivitas kerja tenaga kependidikan di SMA Negeri 12 Makassar. Hal ini sesuai dengan penelitian Turere (2013) yang menyatakan bahwa pendidikan dan pelatihan dapat mempengaruhi peningkatan kinerja karyawan.

Meitaningrum (2013) mengungkapkan pendidikan dan pelatihan yang diikuti oleh pegawai sudah cukup efektif, dilihat dari hasil evaluasi setelah pendidikan dan pelatihan yaitu terjadi perubahan sikap dan perilaku pada diri pegawai dalam menyelesaikan pekerjaannya jauh lebih baik daripada sebelum mengikuti pendidikan dan pelatihan dan kinerja pegawai juga meningkat dari sebelum mengikuti pendidikan dan pelatihan. lebih jauh dari itu, Sommeng (2019) mengungkapkan dalam kaitannya dengan efektivitas Kerja dalam hal ini adalah Kemampuan Guru Dalam Pengembangan Silabus dan RPP mengalami peningkatan setelah menarapkan pelatihan dengan pola Pembinaan Profesional Dengan Pendekatan Kooperatif.

\section{KESIMPULAN \& SARAN}

Pelaksanaan pendidikan dan pelatihan mempunyai hubungan signifikan terhadap efektivitas kerja tenaga kependidikan di SMA Negeri 12 Makassar. Hasil perhitungan uji pvalue pada taraf signifikansi $\alpha=0.05$ dan $\mathrm{n}=$ 12 dengan pengujian 2 pihak $\mathrm{dk}=\mathrm{n}-2=48-2=$ 46, diperoleh $0,02<0,05$.

Faktor-faktor yang mempengaruhi efektivitas kerj adalah (a) Waktu, (b) Tugas, (c) Produktivitas, (d) Motivasi, (e) Evaluasi Kerja, (f) Perlengkapan dan Fasilitas, (g) Lingkungan Kerja, dan (h) Kemampuan Intelektual, (i) Pengawasan.

Berdasarkan kesimpulan yang diperoleh, maka rekomendasi yang disarankan adalah:

(1) Pada pihak sekolah untuk meningkatkan kemampuan kerjanya, sebagai proses penumbuhan intelektualitas sehingga kecemasan menghadapi perubahanperubahan dimasa-masa mendatang dapat dikurangi.
(2) Pendidikan dan pelatihan perlu ditingkatkan kepada tenaga pendidik di SMA Negeri 12 Makassar, terutama pendidikan dan pelatihan (diklat) teknis fungsional, karena diklat ini berkenaan langsung dengan peningkatan pengetahuan dan ketrampilan dalam melaksanakan tugas pekerjaan para tenaga pendidik.

Makin banyak guru yang mengikuti pendidikan dan pelatihan maka makin meningkat juga efektivitas mengajarnya.

\section{DAFTAR PUSTAKA}

Anonim, B. P., \& Referensi, B. (2000). Undang-Undang No. 43 Tahun 1999 Tentang Perubahan Undang-Undang Nomor 8 Tahun 1974 Tentang PokokPokok Kepegawaian. Sinar Grafika, Jakarta

Meitaningrum, D. A. (2013). Efektivitas Pendidikan dan Pelatihan dalam Meningkatkan Kinerja Pegawai (Studi pada Badan Kepegawaian Daerah Kabupaten Malang). Jurnal Administrasi Publik, 1(3), 192-199.

Siagian, S. P. (2001). Organisasi dan prilaku administrasi. Jakarta: Gunung Agung.

Soekidjo, N. (2009). Pengembangan Sumber Daya Manusia. Jakarta: Rineka Cipta

Sommeng, A. (2019). Peningkatan Kemampuan Guru Dalam Pengembangan Silabus Dan RPP Melalui Pola Pembinaan Profesional Dengan Pendekatan Kooperatif. JIKAP PGSD: Jurnal Ilmiah Ilmu Kependidikan, 3(3), 78-88.

Stan, K. (1993). Aspek Manusiawi dalam Organisasi.

Sulistiyani, A. T. Rosidah, 2003, Manajemen Sumber Daya Manusia. Yogyakarta: Graha Ilmu.

Turere, V. N. (2013). Pengaruh pendidikan dan pelatihan terhadap peningkatan kinerja karyawan pada Balai Pelatihan Teknis Pertanian Kalasey. Jurnal EMBA: Jurnal Riset Ekonomi, Manajemen, Bisnis dan Akuntansi, 1(3).

Undang-Undang, R. I. (2003). Nomor 20 Tahun 2003 tentang Sistem Pendidikan Nasional, Pasal 3. Jakarta: Sekretariat Negara RI. 